\title{
INTERANNUAL DIFFERENCES IN EMPLOYEE MOTIVATION IN MANUFACTURING ENTERPRISES IN SLOVAKIA
}

\begin{abstract}
Differences in employee motivation in Slovak manufacturing enterprises during the years 2013 and 2014 are analysed in the paper. Independent samples t-test is used to compare the equality of averages and to calculate the significance level p for individual motivation factors. Definition of the significant increase or decrease of the average level of motivation factors and the comparison of an order of the importance of motivation factors in the year 2013 and 2014 are the findings of the paper. Despite no significant change in various motivation factors they need to be included in the motivation programme of enterprises owing to their importance. Statement that the enterprise management should pay adequate attention to motivation programmes updating because of the interannual changes in employee needs is the research finding. Future development of the level of employee motivation can be predicted following the findings.
\end{abstract}

Keywords: Motivation programme, employee motivation, two-sample t-test.

\section{Introduction}

Current financial crisis affecting the global economy started in the USA in early 2007. It became evident in Slovakia in the second half of 2008. Hardly anybody expected such a high impact of the financial crisis on the global economy. Subsequent problems of many financial institutions and uncertainty and risk in the financial markets caused mainly American but also European economy to slow down [1]. Interconnection among countries and globalisation in relations caused a domino effect. Global economy went down and will go down until the crisis hits the rock bottom. On the other hand, economic crisis can initiate also cleansing and structural processes in enterprises. Several enterprises experience the problem how to motivate staff remaining in the enterprise after restructuring and downsizing the workforce, without having to increase financial resources. An ideal way how to do it is to start using other forms of motivation and to invest in the development of remaining staff. The objective of our paper is to compare interannual differences in the level of motivation in Slovakia, to define potential significant interannual change and to mention a need to adapt employee motivation.

\section{Strategies of employee motivation and motivation programmes}

The process of employee motivation should mainly include basic needs of employees. Their economic conditions are poor, especially at the present time when there is no job security and they reassess their individual needs. Therefore, the role of managers is to update motivation programmes to motivate and stimulate employees in the right way and not to take advantage of the situation [2 and 3]. One of the most important factors of employee motivation is to show an interest in them, employees need to feel valued and important for the enterprise [4 and 5]. Good workplace relations are another way how to support staff motivation. Managers show adequate appreciation to their employees more often. On the other hand, managers can lose their employees' respect by showing much appreciation. The right or effective style of management includes also information about performance results of employees whereby managers highlight positive results and discuss strengths and weaknesses affecting the job performance [6]. Some other methods can be used to manage the period of crisis by means of non-monetary rewards of employees - to restructure teams, arrange educational activities in the enterprise, train employees, offer language and IT courses, management training, professional courses, seminars and trainings furthermore to benefit by several outsourcing tools of the market

\footnotetext{
* ${ }^{1}$ Rudolf Kampf, ${ }^{2}$ Milos Hitka, ${ }^{2}$ Marek Potkany

${ }^{1}$ Institute of Technology and Business in Ceske Budejovice, Czech Republic

${ }^{2}$ Faculty of Wood Sciences and Technology, Technical University in Zvolen, Slovakia

E-mail: kampf@mail.vstecb.cz
} 
[7]. Many sports activities and various corporate events can be carried out by the enterprise to improve interpersonal skills, too. It is also important to encourage corporate communication especially towards subordinates [8]. Selection of non-monetary rewards should be made by employees. Other way of employee motivation is self-actualization, which means delegation of some competences and responsibilities. However, employees can be motivated also by changes in management system in enterprise. Benefits and motivation programmes which can meet employee needs of selfactualization or their economic requirements can be effective for employees. Effective tools for employers are those which can help them, with low cost, start their employee potential [9].

Motivation programme is, in general, a written document of the enterprise, (mostly internal) the role of which is to recruit new employees or to keep employees in required job positions and to create overall working conditions and work environment for them; to set goals and to define methods and tools of work management relating to them; to define ways of influencing negotiation at work and employee behaviour aimed at achieving the setting goals and the schedule of gradually creating conditions to carry out the programme [10]. Motivation programme can be considered a strategic corporate document dealing with:

- measuring motivation level in order to identify areas necessary to improve the motivation,

- creating the environment where employees feel respected and rewarded by the enterprise,

- designing responsible and engaged employee behaviour in the enterprise,

- creating an empowering motivational climate in the enterprise,

- improving skills in the area of human resource management,

- creating operational tasks and new workplaces,

- managing employee performance,

- managing the performance-based rewarding [11].

Forasmuch as goal setting and a set of tools (business operations) to ensure that particular goals will be achieved represent the corporate strategy, its implementation involves creating particular strategies to specify goals of corporate strategy in individual areas (e.g. marketing, investment, product development, finances) [12]. The role of motivation strategies is to create a work environment and to develop policy for improving employee performance [13].

\section{Aim and methodology}

The objective of the paper was to identify changes in employee motivation in manufacturing enterprises in Slovakia during the years 2013 and 2014. A questionnaire was used to determine the level of motivation and to analyse motivation factors in the studied enterprises. The questionnaire consisted of 30 closed questions [10]. It was divided into 2 parts. Socio-demographic and qualification characteristics of employees were searched in the first part of the questionnaire. Basic data about respondents related to their age, sex, seniority, completed education and job position were obtained in this part. The second part consisted of individual motivation factors through which information about work environment, working conditions, applied appraisal and reward system, about personnel management, health and social care system and system of employee benefits as well as information about employee satisfaction or dissatisfaction, value orientation, relation to work and the enterprise or co-workers' relationship in the enterprise can be found out. Motivation factors were in alphabetical order not to affect respondents's decision. Respondents evaluated individual motivation factors by one of the five levels of importance from a pre-defined 5-point rating scale, 5 - the most important and 1 - unimportant. The inquiry survey ran during the years 2013 and 2014. Questionnaires were sent to the respondents via e-mail, mail or were completed in a form of personal interview. Representative sampling unit consisted of 11,263 respondents. At first, obtained values were evaluated on the basis of mean values of individual motivation factors using average [14]:

$\bar{x}=\frac{x_{1}+x_{2}+x_{3}+\cdots+x_{n}}{n}=\frac{1}{n} \sum_{i=1}^{n} x_{i}$

where: $n=$ the size of the sample (number of questionnaires)

$x_{i}=$ the value of variable ith statistical unit.

Subsequently the questionnaires were evaluated using the programme STATISTICA 7. Descriptive statistics was used to describe the primary sampling unit. Statistical characteristics, which compressed information about studied primary sampling units into smaller number of numerical characteristics and made mutual comparison of sampling units easier (years 2013 and 2014), were computed for each motivation factor (real, required). Each motivation factor was described in summary by basic characteristics of size and variability of quantitative features - averages $\bar{x}$, standard deviations $s_{x}$ and coefficients of variation. Subsequently, the results were compared by inductive statistics. Besides simple comparison of descriptive characteristic values, considering the selected type of obtained data, testing the equality of averages and standard deviations of primary sampling units was carried out. The purpose of testing was to verify statistical significance of differences in averages and standard deviations of individual motivation factors in the studied enterprises so that the fact that detected differences of descriptive characteristics at the selected level of significance $\alpha$ were not caused only by the mistake made by representative sampling, was eliminated. The null hypothesis vs. the alternative hypothesis was tested, they were as follows:

$H_{0}: \mu_{1}=\mu_{2}$ vs. $H_{1}: \mu_{1} \neq \mu_{2}$

$H_{0}$ : we suppose that the averages of studied motivation factors (required, real) in the studied period are equal and at the same 
time we suppose that the difference between them, if any, is owing to the random variation of results.

$\mathrm{H}_{1}$ : we suppose that the averages of studied motivation factors (required, real) in the studied period are not equal and at the same time we suppose that the difference between them, if any, is not caused only by the random variation of results.

The random variable $t$ was used as a test criterion. The Student's $t$ distribution was as follows [14]:

if $\sigma_{1}^{2}=\sigma_{2}^{2} ; X_{1}$ a $X_{2}$ are homogenous

$$
t=\frac{\bar{x}_{1}-\bar{x}_{2}}{\sqrt{\frac{n_{1} \cdot s_{1}^{2}+n_{2} \cdot s_{2}^{2}}{n_{1}+n_{2}-2} \cdot \frac{n_{1}+n_{2}}{n_{1} \cdot n_{2}}}}
$$

if $\sigma_{1}^{2} \neq \sigma_{2}^{2} ; X_{1}$ a $X_{2}$ are non-homogenous

$$
t=\frac{\bar{x}_{1}-\bar{x}_{2}}{\sqrt{\frac{s_{1}^{2}}{n_{1}-1}+\frac{s_{2}^{2}}{n_{2}-1}}}
$$

In the end of the test we compared $t$ to $t_{a / 2 ; \rho}$ in a case of $t \leq t_{\alpha / 2 ; f}, H_{0}$ was not rejected and the difference was not considered significant but in a case of $t>t_{\alpha / 2 ; f}, H_{0}$ was rejected at the level of significance of $5 \%$ and the alternative hypothesis $H_{1}$ was accepted.

\section{Results}

Analyses of motivation in manufacturing enterprises were focused on the manufacturing enterprises in Slovakia all along. They were carried out in almost all regions of Slovakia using random selection method and the structured questionnaire. 7,009 employees of the manufacturing enterprises in Slovakia were analysed by the end of the year 2013. Other 4,254 employees of Slovak manufacturing enterprises were analysed in the year 2014. Respondents evaluated individual motivation factors in the questionnaire by one of the five levels of importance from a predefined 5-point rating scale Questionnaire evaluation was carried out from the data matrix with number of employees $x$ number of motivation factors. Stated matrix is a data entry form for carrying out the statistical analysis of motivation factors.

Considering the independence of representative sampling units and their big sizes a two-sample t-test for independent samples at the same or different variances was used. The null hypotheses about the equality of two averages of representative sampling units were tested. The null hypothesis about the equality of mean values of individual motivation factors was tested at the significance level $\alpha=0.05$. Results are shown in Table 1 . Motivation factors with significant change are in bold. A line graph (Fig. 1) was created following the results. During the financial crisis motivation factors like atmosphere in the workplace, job security, supervisor's approach, fair appraisal system, basic salary are the most important for the employees. The less interesting motivation factors for employees are physical effort at work, name of the company, prestige, region's development. Despite a visual form of the level of motivation in 2013 and 2014 we tested the significance level $p$ for individual motivation factors using t-test. Results of the analysis are shown in Table 1.

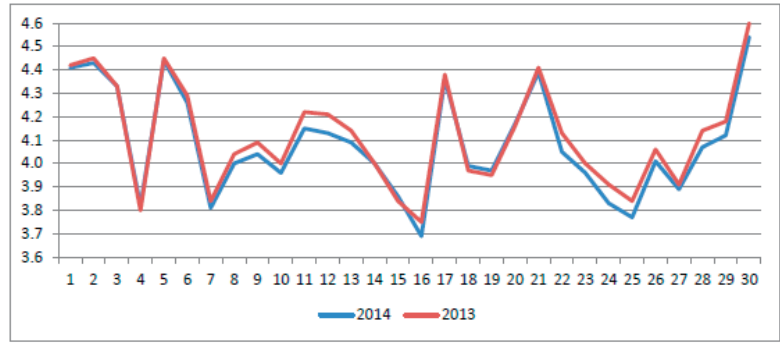

Fig 1 Comparison of averages of motivation factors Source: Own data processing

On the basis of the results we can draw following conclusions. The most important motivation factors are: atmosphere in the workplace, job security, supervisor's approach, fair appraisal system, basic salary. From all of them only basic salary shows a significant increase. Significant difference (requirement raise) was determined in 14 motivation factors: opportunity to apply one's own ability, workload and type of work, information about performance results, working time, work environment, job performance, prestige, stress, mental effort, mission of the company, region's development, education and personal growth, free time, recognition. Even though, there were no significant differences in other motivation factors we consider them important from a long-term point of view. Considering their importance it is necessary to implement them in the motivation programmes of enterprises.

Other important findings of our survey are following statements:

- in principle, employees do not change motivation requirements interannaully,

- employees are motivated by motivation factors not important for them until now.

Following the mentioned facts we can suggest giving adequate attention to motivation programme updating because motivation needs of employees can change interannually.

\section{Conclusion}

At the present time many enterprises do not want or do not consider important to develop and to train staff. Later on, it can affect the performance of enterprise because of the staff performance decrease, a subsequent fall in profits and an increase 


\begin{tabular}{|c|c|c|c|c|c|c|}
\hline & $\begin{array}{c}\varnothing \\
2013\end{array}$ & $\begin{array}{c}\varnothing \\
2014\end{array}$ & $\mathrm{t}$ & $\begin{array}{c}\mathrm{p} \\
\text { variances }\end{array}$ & $\mathrm{F}$ & $\begin{array}{c}\mathrm{p} \\
\text { variances }\end{array}$ \\
\hline Atmosphere in the workplace & 4.41 & 4.42 & -0.56 & 0.579 & 1.02 & 0.391 \\
\hline Good work team & 4.43 & 4.45 & -1.09 & 0.276 & 1.05 & 0.090 \\
\hline Further financial reward & 4.33 & 4.33 & -0.27 & 0.790 & 1.00 & 0.958 \\
\hline Physical effort at work & 3.82 & 3.80 & 0.79 & 0.431 & 1.05 & 0.108 \\
\hline Job security & 4.44 & 4.45 & -0.14 & 0.889 & 1.02 & 0.471 \\
\hline Communication in the workplace & 4.26 & 4.29 & -1.71 & 0.087 & 1.02 & 0.427 \\
\hline Name of the company & 3.81 & 3.84 & -1.29 & 0.198 & 1.32 & 0.000 \\
\hline Opportunity to apply one's own ability & 4.00 & 4.04 & -2.42 & 0.015 & 1.09 & 0.003 \\
\hline Workload and type of work & 4.04 & 4.09 & -2.78 & 0.006 & 1.00 & 0.941 \\
\hline Information about performance results & 3.96 & 4.00 & -2.28 & 0.023 & 1.01 & 0.710 \\
\hline Working time & 4.15 & 4.22 & -4.18 & 0.000 & 1.03 & 0.236 \\
\hline Work environment & 4.13 & 4.21 & -4.71 & 0.000 & 1.06 & 0.039 \\
\hline Job performance & 4.09 & 4.14 & -3.09 & 0.002 & 1.05 & 0.083 \\
\hline Moving up corporate ladder & 4.00 & 4.00 & -0.32 & 0.753 & 1.00 & 0.856 \\
\hline Competences & 3.86 & 3.84 & 1.18 & 0.240 & 1.03 & 0.224 \\
\hline Prestige & 3.69 & 3.75 & -2.83 & 0.005 & 1.02 & 0.395 \\
\hline Supervisor's approach & 4.36 & 4.38 & -1.72 & 0.085 & 1.04 & 0.137 \\
\hline Individual decision making & 3.99 & 3.97 & 0.95 & 0.344 & 1.05 & 0.068 \\
\hline Self/actualization & 3.97 & 3.95 & 1.36 & 0.173 & 1.08 & 0.004 \\
\hline Social benefits & 4.17 & 4.16 & 0.64 & 0.523 & 1.17 & 0.000 \\
\hline Fair appraisal system & 4.39 & 4.41 & -1.52 & 0.128 & 1.04 & 0.160 \\
\hline Stress/limitation of stress in the workplace/ & 4.05 & 4.13 & -4.07 & 0.000 & 1.24 & 0.000 \\
\hline Mental effort & 3.96 & 4.00 & -2.05 & 0.040 & 1.11 & 0.000 \\
\hline Mission of the company & 3.83 & 3.91 & -2.95 & 0.003 & 3.25 & 0.000 \\
\hline Region's development & 3.77 & 3.84 & -2.83 & 0.005 & 1.93 & 0.000 \\
\hline Education and personal growth & 4.01 & 4.06 & -3.18 & 0.001 & 1.04 & 0.207 \\
\hline Relation to the environment & 3.89 & 3.91 & -1.25 & 0.213 & 1.08 & 0.006 \\
\hline Free time & 4.07 & 4.14 & -4.18 & 0.000 & 1.03 & 0.316 \\
\hline Recognition & 4.12 & 4.18 & -3.55 & 0.000 & 1.13 & 0.000 \\
\hline Basic salary & 4.54 & 4.60 & -3.68 & 0.000 & 1.08 & 0.007 \\
\hline
\end{tabular}

Source: Own data processing

in expenses. Enterprises have to be aware of expenses relating to education in comparison to business start-up costs. Teplicka [15] incorporated all motivation factors into possibilities to reduce costs whilst the most important factor during the ongoing financial crisis is to preserve good name of the company and brand, and to improve performance and product or service quality as well. From the point of view of employees an enterprise cannot work when employer does not respect employment contract or promises made to staff. Fulfilling the tasks as well as the behaviour in the workplace, correct communication and openness belong among corporate values [16].
We can also state that during recession employees are fully aware of the importance of job security and moreover, of the fact that employers are not able to provide financial reward to them. Therefore, enterprises should focus on the motivation through developing motivation factors based on interpersonal relationship and job security. During recession employers tend to enhance motivation thereby to increase job satisfaction what is in accordance with individual factors defined in Maslow's hierarchy of needs [17]. Detailed analysis of individual motivation factors allows us to assume that at the present time:

- impact of motivation factors increases and employees consider them more motivating, 
- success as well as recognition, personal growth and a job itself become the most important motivation factor,

- employee dissatisfaction with a work control and subsequent variability of financial reward increase,

- number of factors considered neutral by employees decreases and they accept an opinion that supervisors should not concentrate on the areas like private life and relationship with subordinates.

During recession it is very important to provide job security and create reliable mutual relationships to employees. It can be achieved through effective communication. However, employers do not give adequate attention to this need. Research studies show that employers only rarely allow their staff to meet this need. Motivation factor - reward, recognition, and delegating tasks to employees can be seen as effective motivation factors as well.

\section{Acknowledgement}

This paper has been supported by the project VEGA No. 1/0268/13 "Perspectives of facility management application for the increasing of competitiveness within the woodprocessing and forestry companies in the context of outsourcing principles".

\section{References}

[1] BLASKOVA, M.: Creative Proactive-concluding Theory of Motivating. Business: Theory and Practice, vol. 11, No. 1, 2010, $39-48$. ISSN 1648-0627

[2] BLASKOVA, M., HITKA, M.: Model of Employee Motivation Management in Manufacturing Enterprises (in Slovak), Technicka univerzita : Zvolen, 2011, 171 p., ISBN 978-80-228-2296-1.

[3] HERZKA, P., FUKSOVA, N.: Process of Employee Motivation in Manufacturing Enterprise (in Slovak), J. of Management and Economics, vol. 1, No. 2, 2009, 126-138, ISSN 1337-9488.

[4] POTKANY, M.: Personnel Outsourcing Processes, Economics and Management: Scientific Economic J. (in Czech), vol. 11, No. 4, 2008, TU Liberec, 2008, 53-62, ISSN 1212-3609.

[5] HITKA, M.: Model of Employee Motivation Analysis in Manufacturing Enterprises (in Slovak), Technicka univerzita : Zvolen, 2009, 150 p., ISBN 978-80-228-1998-5.

[6] STACHOVA, K., STACHO, Z.: Employee Allocation in Slovak Companies. Business: Theory and Practice, vol. 14, No. 4, 2013, 332-336, Vilnius, ISSN 1648-0627 (doi: 10.3846/btp.2013.35)

[7] STACHO, Z, URBANCOVA, H., STACHOVA, K.: Organisational Arrangement of Human Resources Management in Organisations Operating in Slovakia and Czech Republic. Acta Universitatis Agriculturae et Silviculturae Mendelianae Brunensis, vol. LXI, No. 7, 2787-2799, 2013, ISSN 1211-8516. (doi: org/10.11118/actaun 201361072787)

[8] RIMARCIK, M.: Statistics in Practice (in Slovak), 2007, 200 p., ISBN 978-80-969813-1-1.

[9] SCHEER, L.: Biometrics (in Slovak), Vysokoskolska ucebnica, Technicka univerzita vo Zvolene, 2007. ISBN 978-80228-17233.

[10] StatSoft. Inc. 2004. STATISTICA (data analysis software system), version 7. www.statsoft.com.

[11] SUlgAN, M., SOSEDOVA, J.: Procurement of Materials and Components for Manufacturing Activity, Communications Scientific Letters of the University, 16 (2), 58-62, 2014, ISSN 1335-4205.

[12] ZAVADSKA, Z., ZAVADSKY, J., SIROTIAKOVA, M.: Process Model and its Real Application in the Selected Management Areas. E a M: Ekonomie a Management, vol. 16, No. 1, 2013, 113-127, ISSN 1212-3609.

[13] TEPLICKA, K.: Progressive Management Trends in Manufacturing Enterprises (in Slovak), Ekonomie a management, vol. 7, No. 4, 2004, 26-31, ISSN 1212-3609.

[14] VETRAKOVA, M. et al.: Human Resources and Their Management (in Slovak), EF UMB Banska Bystrica: Bratia Sabovci, s. r. o. Zvolen, 2011, 206 p., ISBN 978-80-557-0149-3.

[15] ROLKOVA, M.: Participative Management Style and its Relation to Employee Willingness to Accept Job offer in the Same Company Once Again, Communications - Scientific Letters of the University of Zilina, 15 (4), 2013, 96-99, ISSN 1335-4205.

[16] VODAK, J., SOVIAR, J., LENDEL, V.: Identification of the Main Problems in Using Cooperative Management in Slovak Enterprises and the Proposal of Convenient Recommendations, Communications - Scientific Letters of the University of Zilina, 15 (4), 2013, 63-67, ISSN 1335-4205.

[17] KROPIVSEK, J., JELACIC, D., GROSELJ, P.: Motivating Employees of Slovenian and Croatian Wood Industry Companies in Times of Economic Downturn, Drvna industrija, vol. 62, No. 2, 2011, Zagreb, 97-103, ISSN 0012-6772 (doi: 10.5552/ drind.2011.1040). 